\title{
Development, Implementation, and Evaluation of an Equitable Futures Program for Urban Public Schools
}

\author{
Christine J. Yeh, Ph.D. ${ }^{1}$, Stephanie Khaziran, M.A. ${ }^{2}$, Mio Tsukamoto Berk, M.A. ${ }^{3}$ \& Emily Hong Daniel, M.A. ${ }^{4}$ \\ ${ }^{1}$ School of Education, University of San Francisco, San Francisco, CA, USA \\ ${ }^{2}$ Gateway High School, San Francisco Unified School District, San Francisco, CA, USA \\ ${ }^{3}$ The Bay School of San Francisco, San Francisco, CA, USA \\ ${ }^{4}$ San Francisco Waldof School, San Francisco, CA, USA \\ Correspondence: Christine J. Yeh, Ph.D., School of Education, University of San Francisco, San Francisco, CA, \\ USA. Tel: 1-415-422-2347. E-mail: cjyeh@usfca.edu
}

\author{
Received: February 4, 2018 Accepted: March 19, 2018 Online Published: April 4, 2018 \\ doi:10.5539/jedp.v8n1p162 URL: http://doi.org/10.5539/jedp.v8n1p162
}

This project was made possible from a grant from the Koret Foundation, San Francisco, California.

\begin{abstract}
We describe the development, implementation, and evaluation of a culturally-responsive college access program, Make It Happen, aimed at increasing educational opportunity for historically-targeted middle and high school students. The sample included 254 participants who participated in the evidence-based 10 -session program. These participants completed surveys before and after the program which inquired about their (1) school engagement, (2) social connectedness, and (3) academic and college help-seeking self-efficacy. T-test analyses were conducted and determined the participants at post-test, felt significantly more engaged at school, more connected to others, and more self-efficacious in seeking support for information about academics and college. The authors describe the importance of working with teachers, school staff, and counselors to foster a supportive and positive exploratory space for students who could benefit from learning about their future options (Beesley, 2004; Yeh, Ching, Okubo, \& Luthar, 2007).
\end{abstract}

\section{Introduction}

\subsection{Urban Public Schools}

The narratives about historically targeted, low-income adolescents in the school system include deficit-oriented perceptions in regards to their educational achievement, and many negative social and health outcomes (Fuligni \& Hardway, 2004). We assert that middle and high school students have many academic, personal, and cultural assets to offer in educational settings (Yeh, Borrero, Tito, \& Petaia, 2014). However, due to structural racism and assimilationist practices that give preference to assertive, help-seeking, students with specific college knowledge, many youths do not have the opportunity, access, and resources to pursue post-secondary educational plans. A university in California has partnered with local public school to develop, implement, and evaluate a college access program for culturally diverse students in middle and high school. This program, Make It Happen, provides exploratory and interactive spaces of inclusion and belonging to foster students' school engagement, social connection, and academic and college help-seeking self-efficacy (Johnson, 2009; LaRoche \& Tawa, 2011).

Specifically, we believe that middle and high school students' college interests are very much linked with the ecological systems in which they interact (Borrero \& Yeh, 2010; Bronfenbrenner, 1997; Ma \& Yeh, 2005). These systems include their experiences at home, in neighborhoods, and at school. In terms of the context of school, research has consistently shown that school involvement and bonding to teachers, are essential in students' academic achievement, career development, and future educational plans (Kenny, Blustein, Haase, Jackson \& Perry, 2006; Shea, Ma, \& Yeh, 2007). Schools are also sites of possibility and impossibility that can serve as socializing agents for historically targeted and ethnic minority youth (Trickett \& Formosa, 2008).

We believe that schools must find ways to systemically support all students in their future success. In particular, we believe that school counselors have the great potential to serve as advocates who partner with students in 
developing their future trajectories. School counselors also have the capacity to support students in developing a strong sense of self-efficacy around preparing for, applying to, and attending, college.

Schools can be a space where youths, especially urban students of Color feel they belong or don't belong (e.g. Borrero, Yeh, Cruz, \& Suda, 2012; Deschenes et al., 2001). This academic isolation distances students from the narratives around academic success (Weis, 2003), and possibilities for educational citizenship (Kliewer \& Biklen, 2007). Specifically, the predominant discourse on standardized tests and the well-chronicled achievement gap fails to acknowledge the deeper issue - many ethnic minority students are disconnected and disengaged from school, and therefore cannot envision educational opportunities after graduation (Banks, 2008; Duncan-Andrade, 2007). We believe that school counselors are advocates who play an important role in increasing students' school engagement (Slaten \& Elison, 2015) through building their social connections and cultural empowerment.

Developing strong social relationships and sense of community at school may encourage students to feel a sense of belonging and encourage their personal, academic, and career development (Nasir \& Saxe, 2003). Social connection specifically has been found to positively influence academic performance and protect against adverse social and educational outcomes (Demaray \& Malecki, 2002). School-based programs that highlight social connection and support may foster ethnic minority students' cultural adjustment (Yeh, 2003; Yeh, et al. 2003; Yeh et al. 2005) social skills, self-concept, flexibility, and academic competence (Demaray \& Malecki; 2002). Social connections may also buffer the impact of perceived discrimination (Liang, Alvarez, Juang, \& Liang, 2007) and individual, cultural, and institutional levels of racism in schools (Borrero, Yeh, Tito, \& Luavasa, 2010). Social support may be especially critical during the college application process which has the potential to categorize youth who may come from marginalized communities.

We investigate middle and high school seniors' experiences and attitudes before and after their participation in an educational opportunity program, Make It Happen, that helps students understand and navigate the college, financial aid, and scholarship application process. In addition, this program is framed in a cultural assets model (Yeh et al. 2014), in which students learn how to utilize the strengths of their family and community to support their future trajectories.

\subsection{School Engagement}

School engagement refers to students' overall interest in school as well as their relationships with teachers (Wehlage, Rutter, Smith, Lesko, \& Fernandez, 1989) and has been associated with strong academic performance (Perry, Liu, \& Pabian, 2010). Previous research has revealed the positive relationship between participation in high school-based programs and student engagement (Yeh \& Borrero, 2012). In large, urban, public school settings, students may feel unwelcome and alienated (Nasir \& Saxe, 2003). Hence, an innovative school-based program that provides information on, and support for, college access has the potential to foster school engagement, bonding to teachers, social connection, and academic and career self-efficacy skills (Shea, Ma, Yeh, Lee, \& Pituc, 2009).

\subsection{Social Connectedness}

Research has indicated that feelings of being supported contribute to positive ethnic identities (Yeh \& Borrero, 2012), school engagement (Libbey, 2004), and career development (Turner, \& Lapan, 2002) among historically marginalized youth. Social support has also been found to increase ethnic minority youths' interpersonal skills (Yeh, Okubo, Ma, Shea, Ou, \& Pituc, 2008a). We also believe that fostering social connections among a group of culturally diverse students contributes to the development and use of positive coping skills to deal with educational and social stressors (Struthers, Perry, \& Menec, 2000). In this context, it was also critical to consider how relational support is shaped by cultural experiences in school. This brings innovation to school counseling practice, and allows for intersectional identities (e.g., gender, race, income level) to be incorporated into counseling and education practice.

\subsection{Academic and Career Self-Efficacy}

Students who are the first in their family to apply to college may not have access to the resources that their non-first-generation counterparts have. For example, first generation students typically do not have parents or guardians who have experience completing college applications and financial aid forms. These same students may not know who to ask for support and help in the college application process. In addition, they may not have access to role models or mentors in the community who encourage them to envision a range of future trajectories that extend beyond everyday stereotypes (Liang, Spencer, West, \& Rappaport, 2013; Phinney, Dennis, \& Chuateco, 2005; Somers Owens \& Piliawsky, 2009). Hence, we also wanted to develop and deliver a college access program that could provide more equitable college access to students by developing their academic and career help-seeking self-efficacy. We also wanted to highlight the many individual, community, and familial strengths that they have 
and how these assets can help them navigate the college application process.

For example, researchers who implemented culturally responsive programs for ethnic minority students in a New York City school reported increased feelings of academic and career help-seeking self-efficacy when they engaged in a future planning curriculum (Shea, et al. 2009). Such resources allow students to develop positive cultural and academic identities (Nasir \& Saxe, 2003) and career trajectories along with other students in the program (Shea, Ma, \& Yeh, 2007). Hence, a school-based program that provides support for future plans, college access, and educational opportunity has the potential to foster social connection, school engagement, and academic and career help-seeking skills.

\subsection{Description of the Make It Happen program}

The Make It Happen program was initially designed and implemented in a participatory way, in which students, university faculty, school staff, mentor counselors, and counselors in training partnered and worked together to design the group curriculum based on the students' needs and input (Nelson \& Johnson, 1999; Smith, Davis, \& Bhowmik, 2010). The initial curriculum was tested and improved through a pilot study at nine schools. University faculty then continued to collaborate with mentor counselors and school counselor trainees to plan and cover topics that were important when applying to college. This list of topics related to family and community support, college knowledge, graduation requirements, financial aid, college applications, essay writing, and transition to college. Moreover, the groups were designed so each school counselor used experiential activities to increase social connections, school engagement, and academic and career help-seeking self-efficacy (see Roaten, \& Schmidt, 2009) and to create open spaces for self-exploration, empowerment, and understanding about one's community and cultural assets.

After the pilot study, qualitative and quantitative data were analyzed and the curriculum was adapted to cover culturally-centered strategies and techniques (Groulx \& Silva, 2010; Smith, Geroski \& Tyler, 2014) across five main modules. Each module was two sessions long and included: Social Connections and Support, Family and Community Support, College Knowledge, Financial Aid, and Future Planning. Each module was explored across two sessions for a total of 10 sessions (see Table 1 for a description of each session). Most sessions began with an icebreaker and included an interactive activity. Each session was framed in a cultural assets model, evidence-based, and linked with key standards of the American School Counselor Association.

\subsection{Research Question and Hypotheses}

The specific research question is listed below.

(1) Do participants in the Make It Happen program have significantly higher levels of (a) social connection, (b) school engagement, (c) academic and college help-seeking self-efficacy, at the end of the program in comparison to the beginning of the program (at post-test in comparison to pre-test)?

We hypothesized that students in the Make It Happen program will have significantly higher levels of (a) social connection, (b) school engagement, (c) academic and college help-seeking self-efficacy at post-test in comparison to pre-test.

\section{Method}

\subsection{Sample}

The sample included 254 middle and high school students who were attending 15 high schools and four middle schools in the San Francisco Bay Area. We included a range of grade levels to assess the impact of the group across ages. The race of the participants was as follows: $25.2 \%(\mathrm{n}=64)$ Asian American/Southeast Asian/South Asian 36.2\% $(\mathrm{n}=92)$ Latina/o 9.8\% $(\mathrm{n}=25)$, African American 5.5\% $(\mathrm{n}=15)$ Pacific Islander, $14.6 \%(\mathrm{n}=37)$ multiracial, $4.3 \%(\mathrm{n}=11)$ white and $4 \%(\mathrm{n}=10)$ listed another race. Their ages ranged from $11-20$ years $(\mathrm{SD}=$ 1.95). In terms of gender/sex, 53.1\% $(\mathrm{n}=135)$ described themselves as female, $41.3 \%(\mathrm{n}=108$ as male, 3.9\% $(\mathrm{n}=$ 10) declined to state, and .4\% $(\mathrm{n}=1)$ described themselves as transmale/transfemale/genderqueer. The sample was predominantly low-income and $85 \%$ of the sample qualified for free lunch. Across the sample, $37.4 \%(\mathrm{n}=95)$ had a parent or guardian who attended some college. Hence, $63.6 \%(\mathrm{n}=159)$ were considered first generation.

\subsection{Recruitment Procedure}

School counselors worked with mentor (supervising) counselors and teachers to refer students to the Make It Happen program. In particular, they made special efforts to support students who had no future plans and who would be the first in their family to go to college. School counselors also tried to recruit historically targeted students of Color with the greatest need for college access support. Groups were offered during lunch, after school, or during the school advisory (free) period. In this regard, we used a purposive sampling method. At the beginning 
of the first session of the group, participants completed a survey packet with the following measures (1). Demographic information sheet, (2). Social Connectedness Scale; (3). The Bonding to School survey (measures school engagement and bonding to teachers) and the (4). Academic and College Help-seeking Scale. These same surveys were administered to the same participants 10 weeks (sessions) later at the end of the Make It Happen group.

\subsection{Instruments}

Demographic Information Sheet: The Demographic information sheet inquired about age, grade, gender/sex, race, income, and parents' education level.

The Bonding to School (BTS) questionnaire is a measure designed to measure feelings of school connection among middle and high school students (Wehlage, et al. 1989). It has also been used to study the associations between attachment to school and student behavior (Fletcher, Darling, Steinberg, \& Dornbusch, 1995). The BTS is comprised of two subscales; one asks about the extent to which the student feels a bond to teachers and the second subscale measures their school interest or connection. It is asserted that these two scales, combined, represent school engagement inasmuch as they include the emotional (feeling supported at school) and psychological (being interested in/valuing school) components of the construct. The Bonding to Teachers (BT) subscale contains six items that evaluate whether the student feels supported by teachers at their school. Sample items include "My teachers care about how I am doing". The School Interest (SI) subscale consists of five items that assess the student's interest in and perceived value of school. A sample item includes: "Success in life does not have much to do with the things studied in school". The participant indicates whether he/she agrees or disagrees with each statement, using a Likert-type scale. The alpha coefficient for the combined scale was .92.

Academic and College Help-Seeking Scale (ACHSS; Yeh, Okubo, Cha, Lee, \& Shin, 2008b) is a 10-item scale that measures a students' self-efficacy around seeking help for academic, career, or college related activities. Five items focus on academic help-seeking and five items focus on college and career help-seeking. A sample item includes, "I know who to ask if I need help learning about college applications." The alpha coefficient for the academic help-seeking scale was .94. The alpha coefficient for the college help-seeking scale was .96. The scale has been used with ethnic minority high school students with strong reported reliability (Ma \& Yeh, 2005; Yeh et al; 2008b).

Social Connectedness Scale (Lee, \& Robbins, 1995). The original SCS is an 8-item, Likert-type scale designed to measure interpersonal closeness in an individual's social world and the level of difficulty in maintaining this closeness. The sample items are "Even around people I know, I don't feel that I really belong." and "I don't feel I participate with anyone or any group." There are no subscales. Rather, an overall sense of social connectedness is assessed by summing all of the items on the scale. The alpha coefficient for this scale was .91 . The scale has been used with ethnic minority high school students with strong reported reliability (Ma \& Yeh, 2005; Yeh et al; 2008b).

\section{Results}

Preliminary descriptive analyses were performed to confirm that the data had a normal distribution and replicated norms found in previous research. Next, we tested to see if the specific variables (survey scores) differed based on gender, age, grade level, school, generation, and parent education level. No demographic dissimilarities were found on the dependent variables of interest so we did not control for demographic variables in our pre-post analyses.

A series of paired samples t-tests (dependent samples t-tests) were conducted to examine change from before and after the group on the outcomes of interest. Paired samples t-tests determined a significant decrease in students' feelings of disconnection from pre-test $(M=16.20, S D=7.86)$ to post-test $(M=19.13, S D=7.96), \mathrm{t}(253)=4.10$, Cohen's $d=.55$; an increase in school engagement from pre-test $(M=25.07, S D=6.17)$ to post-test $(M=26.69$, $S D=5.92), \mathrm{t}(253)=-3.48$, Cohen's $d=.52$; a significant increase in academic self-efficacy from pre-test $(M=$ $17.34, S D=4.64)$ to post-test $(M=19.20, S D=4.16), \mathrm{t}(253)=-5.72$, Cohen's $d=.56$; and a significant increase in college self-efficacy from pre-test $(M=20.02, S D=5.58)$ to post-test $(M=24.16 S D=4.68), \mathrm{t}(253)=-10.12$, Cohen's $d=.49$.

\section{Discussion and Significance}

These results indicate that students who participated in the Make It Happen program tended to have significantly higher levels of social connection, school engagement, and academic and college help-seeking self-efficacy after the program. These results speak to the importance of exposure to multiple college and career options, relationship building, and the need for practical, skills-focused, innovative, and strength-based programs that support educational opportunity among youth in urban schools. 
Consistent with our hypotheses, students in the Make It Happen program reported increased levels of social connectedness at the time of the post-test. Increased support and connection from others is especially important for historically targeted youth who tend to rely on peer relationships when coping with stressors at school such as racism and negative stereotypes (Yeh, Kim, Pituc, \& Atkins, 2008). This program provided opportunities for participants to share struggles and fears related to their future trajectories in a way that was culturally congruent with their values (Yeh et al. 2014). Moreover, many of the exercises in the program involved working in small groups or pairs, providing space for students to get to know one another.

As expected, participants also reported increased school interest and an elevated bonding to teachers after the group. The Make It Happen program incorporated an authentic approach to understanding how school learning is linked to career trajectories. The program also emphasized the support systems necessary to succeed academically, which includes building connections with teachers. These priorities are what can make a school, and therefore academic success, a priority for youth. Low-income, ethnic minority, and first-generation students are so frequently alienated from educational systems that foster academic achievement (Borrero, et al. 2010). Further, the students' reported bonding to teachers reveals that they were more invested in their academics (Yeh \& Borrero, 2012) and as well as in the connections they were developing with students and teachers alike. Being engaged at school supports a feeling of belongingness which can promote students' cultural assets and help them navigate their cultural and academic identities.

Students' heightened sense of academic and career help-seeking self-efficacy at the end of the intervention reveals that the Make It Happen program not only provided a space for participants to bond with students from many different cultural groups (Ensher \& Murphy, 1997), but also offered the youth the chance to think about how to pursue their academic and career goals. Specific sessions in our program provided exercises and role plays to teach students how to get support for academic and career questions and issues. This information included topics such as how to ask a school counselor for help with a personal statement, how to talk to a teacher about difficulty on a test, and how to ask a school administrator for a college reference. Since about $64 \%$ of the participants had a parent/guardian with no college education background, these help-seeking skills were absolutely essential and fostered students' college and academic help-seeking self-efficacy.

The Make It Happen program exemplifies the powerful impact of ecologically-based counseling programs for historically targeted students' educational opportunity. Students in the Make It Happen program reported positive outcomes associated with their relationships with their peers, family, teachers, community, school, and cultural group. These are critical social settings for adolescents and speak to the potential role that counselors have in shaping relational, academic, and cultural experiences. Future counseling interventions for educational opportunity and college access may consider ways to incorporate culturally relevant best practices that promote students' assets and holistic personal, academic, college, and career development (Pérez-Gualdrón, Yeh, \& Russell, 2016).

Another interrelated strength that emerged from the program is the critical role of collaboration and community in counseling interventions. Specifically, the Make It Happen program was designed to include multiple partnerships with individuals in college, academic, community and school settings. For example, as part of the program, students met with role models from their community who were also the first in their family to attend college. These visits from role models provided opportunities for personal interactions with visible mentors (Rhodes \& DuBois, 2008; Rhodes, Spencer, Keller, Liang, \& Noam, 2006). The impact of having a role model or mentor is especially meaningful to their personal, college and reference group identity-making as well as their cultural self-esteem.

\subsection{Limitations}

We caution generalizability due to the specific geographic location of the school settings (urban west coast city). Future studies should test the efficacy of the Make It Happen program across multiple geographic locations. The study was also limited by the use of self-report surveys which are vulnerable to responses impacted by social desirability. Finally, we were unable to gather data from a comparable control group which limited our ability to determine that the change in post-test was indeed due to the impact of the program and not natural maturation and developmental factors. Specifically, at the time of this study, we did not have permission from the schools to collect control group data because that would prevent half of the students (the control group) from receiving the intervention. Since we were focused on supporting high-need students, we prioritized offering this valuable counseling service over having control group data. Future research should include control group data using a delayed intervention methodology.

\section{Implications for Counseling and Research}


The results of this study underscore the importance of developing innovative and culturally responsive counseling services for historically marginalized students to help them develop positive, asset-based and integrated cultural, social, academic, and career identities. While our findings provide strong justification for replication, expansion, and future adaptation of this specific type of college access program, there are two main strengths of the program that we believe have broader and potentially more longstanding advantages for counseling programs in public schools.

A specific strength of the Make It Happen program is the powerful impact it has on culturally diverse adolescents' growth and development. Students in the program reported positive outcomes associated with their relationships with their peers, teachers, community, school, and cultural group. These settings represent critical and formative ecological sites for adolescents and speak to the potential role that counselors can have in shaping relational, academic, and cultural experiences for ethnic minority adolescents. Future counseling interventions for students may consider ways to incorporate culturally relevant best practices that promote students' assets, bonding, and holistic development.

Another interrelated strength that emerged from evaluating this program is the role of collaboration and community in counseling and intervention programs for adolescents. Specifically, the Make It Happen program was designed to include multiple interactions and partnerships with mentor counselors, teachers, university students, university faculty, community members, and school staff. For example, each Make It Happen group was facilitated by a school counselor and supervised by a mentor counselor and university faculty member. Teachers, school staff, and university supervisors provided additional support.

It is clear that the Make It Happen program contributes to many important student outcomes that are academic (i.e., academic and college self-efficacy) as well as non-academic (i.e., social connection and bonding to teachers). There needs to be more rigorous and in-depth data collection and analyses employed to better understand the specific aspects of the culturally-responsive programs so best practices can be identified. For example, future research could explore which main features of the intervention increase students' social connection and school engagement. Overall, the Make It Happen program proved to be most effective in supporting historically marginalized students' equitable futures.

\section{References}

Banks, J. A. (2008). Diversity, group identity, and citizenship education in a global age. Educational Researcher, 37, 129-139. https://doi.org/10.3102/0013189X08317501

Beesley, D. (2004). Teachers' Perceptions of School Counselor Effectiveness: Collaborating for Student Success. Education, 125, 259-271.

Borrero, N. E., \& Yeh, C. J. (2010). Ecological language learning among ethnic minority youth. Educational Researcher, 39(8), 571-581. https://doi.org/10.3102/0013189X10389810

Borrero, N. E., Yeh, C. J., Cruz, I., \& Suda, J. (2012). School as a context for "Othering" youth and promoting cultural assets. Teachers College Record, 114(2), 1-37.

Borrero, N. E., Yeh, C. J., Tito, P., \& Luavasa, M. (2010). Alone and in between cultural worlds: Voices from Samoan students. Journal of Education, 190(3), 47-56. https://doi.org/10.1177/002205741019000306

Bronfenbrenner, U. (1997). Ecological models of human development. In M. Gauvain \& M. Cole (Eds.), Readings on the development of children (pp. 37-43). New York, NY: Worth Publishers.

Camangian, P. R. (2015). Teaching like lives depend of it: Agitate, arouse, inspire. Urban Education, 50(4), 424-453. https://doi.org/0.1177/0042085913514591

Demaray, M. K., \& Malecki, C. K. (2002). The relationship between perceived social support and maladjustment for students at risk. Psychology in the Schools, 39(3), 305-316. https://doi.org/10.1002/pits.10018

Deschenes, V., Cuban, L., \& Tyack, D. (2001). Mismatch: Historical Perspectives on Schools and Students Who Don't Fit Them. Teachers College Record, 103, 525-547. https://doi.org/10.1111/0161-4681.00126

Duncan-Andrade, J. (2007). Gangstas, wankstas, and ridas: Defining, developing, and supporting effective teachers in urban schools. International Journal of Qualitative Studies in Education, 20, 617-638. https://doi.org/10.1080/09518390701630767

Ensher, E. A., \& Murphy, S. E. (1997). Effects of race, gender, perceived similarity, and contact on mentor relationships. Journal of Vocational Behavior, 50(3), 460-481. https://doi.org/10.1006/jvbe.1996.1547

Fletcher, A. C., Darling, N. E., Steinberg, L., \& Dornbusch, S. M. (1995). The company they keep: Relation of 
adolescents' adjustment and behavior to their friends' perceptions of authoritative parenting in the social network. Developmental Psychology, 31, 300-310. https://doi.org/10.1037/0012-1649.31.2.300

Fuligni, A. J., \& Hardway, C. (2004). Preparing Diverse Adolescents for the Transition to Adulthood. The Future of Children, 14(2), 99-119. https://doi.org/10.2307/1602796

Groulx, J. G., \& Silva, C. (2010). Evaluating the development of culturally relevant teaching. Multicultural Perspectives, 12(1), 3-9. https://doi.org/10.1080/15210961003641120

Johnson, L. S. (2009). School contexts and student belonging: A mixed methods study of an innovative high school. School Community Journal, 19, 99-118.

Kenny, M. E., Blustein, D. L., Haase, R. F., Jackson, J., \& Perry, J. C. (2006). Setting the stage: Career development and the student engagement process. Journal of Counseling Psychology, 53, 272-279. https://doi.org/10.1037/0022-0167.53.2.272

Kliewer, C., \& Biklen, D. (2007). Enacting literacy: Local understanding, significant disability, and a new frame for educational opportunity. The Teachers College Record, 109, 2579-2600.

La Roche, M., \& Tawa, J. (2011). Taking back our streets: A clinical model for empowering urban youths through participation in peace promotion. Peace and Conflict, 17(1), 4-21. https://doi.org/10.1080/10781911003769165

Lee, R. M., \& Robbins, S. B. (1995). Measuring belongingness: The social connectedness and social assurance scales. Journal of Counseling Psychology, 42(2), 232. https://doi.org/10.1037/0022-0167.42.2.232

Levitt, M. J., Guacci-Franco, N., \& Levitt, J. L. (1994). Social support and achievement in childhood and early adolescene: A multicultural study. Journal of Applied Developmental Psychology, 15(2), 207-222. https://doi.org/10.1016/0193-3973(94)90013-2

Liang, C. T., Alvarez, A. N., Juang, L. P., \& Liang, M. X. (2007). The role of coping in the relationship between perceived racism and racism-related stress for Asian Americans: Gender differences. Journal of Counseling Psychology, 54(2), 132. https://doi.org/10/1037/0022-0167.54.2.132

Liang, C. T., Alvarez, A. N., Juang, L. P., \& Liang, M. X. (2007). The role of coping in the relationship between perceived racism and racism-related stress for Asian Americans: Gender differences. Journal of Counseling Psychology, 54(2), 132-141. https://doi.org/10/1037/0022-0167.54.2.132

Liang, B., Spencer, R., West, J. \& Rappaport, N. (2013). Expanding the reach of youth mentoring: Partnering with youth for personal growth and change. Journal of Adolescence, 36, 839-848. https://doi.org/10.2016/j.adolescence.2012.10.002

Libbey, H. P. (2004). Measuring student relationships to school: Attachment, bonding, connectedness, and engagement. Journal of School Health, 74, 274-283. https://doi.org/10.1111/j.1746-1561.2004.tb08284.x

Ma, P-W., \& Yeh, C. J. (2005). Factors influencing the career decision status of Chinese American youth. Career Development Quarterly, 53, 337-347. https://doi.org/10.1002/j.2161-0045.2005.tb00664.x

Nasir, N. \& Saxe, G. B. (2003). Ethnic and academic identities: A cultural practice perspective on emerging tensions and their management in the lives of minority students. Educational Researcher, 32(5), 14-18. https://doi.org/10.3102/0013189X032005014

Nelson, M. D., \& Johnson, P. (1999). School counselors as supervisors: An integrated approach for supervising school counseling interns. Counselor Education and Supervision, 39, 89-100. https://doi.org/10.1002/j.1556-6978.1999.tb01220.x

Pérez-Gualdrón, L., Yeh, C. J., \& Russell, L. (2016). Development and evaluation of a culturally-responsive program for ethnic minority high school boys. Journal of School Counseling, 14(13).

Perry, J. C., Liu, X., \& Pabian, Y. (2010). School engagement as a mediator of academic performance among urban youth: The role of career preparation, parental career support, and teacher support. The Counseling Psychologist, 38, 269-295. https://doi.org/10.1177/0011000009349272

Phinney, J. S., Dennis, J. M., \& Chuateco, L. I. (2005). The role of motivation, parental support, and peer support in the academic success of ethnic minority first-generation college students. Journal of College Student Development, 46(3), 223-236. https://doi.org/10.1353/csd.2005.0023

Rhodes, J. E., \& DuBois, D. L. (2008). Mentoring relationships and programs for youth. Current Directions in Psychological Science, 17, 254-258. https://doi.org/10.1111/j.1467-8721.2008.00585.x 
Rhodes, J. E., Spencer, R., Keller, T. E., Liang, B., \& Noam, G. (2006). A model for the influence of mentoring relationships on youth development. Journal of Community Psychology, 34, 691-707. https://doi.org/10.1002/jcop20124

Roaten, G. K., \& Schmidt, E. A. (2009). Using experiential activities with adolescents to promote respect for diversity. Professional School Counseling, 12, 309-314. https://doi.org/10.5330/PSC.n.2010-12.309

Shea, M., Ma, P.-W., \& Yeh, C. J. (2007). Development of a culturally specific career exploration group for urban

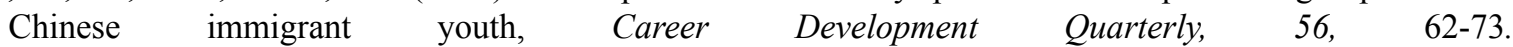
https://doi.org/10.1002/j.2161-0045.2007.tb00020.x

Shea, M., Ma, P-W., Yeh, C. J., Lee, S. \& Pituc, S. T. (2009). Exploratory studies on the effects of a career exploration group for urban Chinese immigrant youth. Journal of Career Assessment, 17, 457-477. https://doi.org/10.1177/1069072709334246.

Slaten, C. D., \& Elison, Z. M. (2015). Interpersonal Process Group Counseling for Educationally Marginalized Youth: The MAGNIFY Program. Journal of School Counseling, 13(17), 1-28. Retrieved from http://www.jsc.montana.edu/articles/v13n17.pdf

Smith, L., Davis, K., \& Bhowmik, M. (2010). Youth participatory action research groups as school counseling $\begin{array}{lllll}\text { interventions. } & \text { Professional }\end{array}$ https://doi.org/10.5330/prsc.14.2.m62r11337332gt54.

Smith, L. C., Geroski, A. M. \& Tyler, K. B., (2014). Abandoning Colorblind Practice in School Counseling. Journal of School Counseling, 12(16). Retrieved from http://www.jsc.montana.edu/articles/v12n16.pdf

Somers, C. L., Owens, D., \& Piliawsky, M. (2009). A Study of High School Dropout Prevention and At-Risk Ninth Graders' Role Models and Motivations for School Completion. Education, 130, 348-356.

Struthers, C. W., Perry, R. P., \& Menec, V. H. (2000). An examination of the relationship among academic stress, coping, motivation, and performance in college. Research in higher education, 41(5), 581-592. https://doi.org/10.1023/A:1007094931292

Trickett, E. J., \& Formoso, D. (2008). The acculturative environment of schools and the school counselor: Goals and roles that create a supportive context for immigrant adolescents. In H. L. K. Coleman and C. J. Yeh (Eds.). Handbook of School Counseling. (pp. 79-94). New York, NY: Taylor \& Francis, Inc.

Turner, S. \& Lapan, R. T. (2002). Career self-efficacy and perceptions of parent support in adolescent career development. The Career Development Quarterly, 51(1), 44-55. https://doi.org/10.1002/j.2161-0045.2002.tb00591.x

Wehlage, G. G., Rutter, R. A., Smith. G. A., Lesko, N., \& Fernandez, R. R. (1989). Reducing the risk: Schools as communities of support. London, U. K.: Falmer Press.

Weis, L. (2003). Constructing the "Other": Discursive renditions of White working-class males in high school. In M. Fine \& L. Weis (Eds.) Silenced voices and extraordinary conversations: Re-imagining schools (pp. 68-87) New York, NY: Teachers College Press.

Yeh, C. J. (2003). Age, acculturation, cultural adjustment, and mental health symptoms of Chinese, Korean, and Japanese immigrant youth. Cultural Diversity and Ethnic Minority Psychology Journal, 9, 34-48. https://doi.org/10.1037/1099-9809.9.1.34

Yeh, C. J., Arora, A. K., Inose, M., Okubo, Y., Li, R. H., \& Greene, P. (2003). The cultural adjustment and mental health of Japanese immigrant youth. Adolescence, 38(151), 481-500.

Yeh, C. J., \& Borrero, N. E. (2012). Evaluation of a health careers program for Asian American and Pacific Islander high school students, Journal of Multicultural Counseling and Development, 40, 227-239. https://doi.org/10.1002/j.2161-1912.2012.00020.x

Yeh, C. J., Borrero, N. B., Lusheck, C., Placencia, L., Kilano, S., Mase, M., Suesue, T., \& Tito, P. (2014). Fostering Social Support, Leadership Competence, Community Engagement and Resilience among Samoan American Youth. Asian American Journal of Psychology, 6, 145-153. https://doi.org/10.1037/a0038545

Yeh, C. J., Borrero, N. E., Tito, P., \& Petaia, L. S. (2014). Intergenerational stories of "othered" youth through insider cultural knowledge and community assets. The Urban Review, 46, 147-168. https://doi.org/10.1007/s11256-013-0249-2

Yeh, C. J., Ching, A. M., Okubo, Y., \& Luthar, S. (2007). Description of a mentoring program for Chinese 
immigrant adolescents' cultural adjustment. Adolescence, 42, 734-747.

Yeh, C. J., Kim, A. B., Pituc, S. T., \& Atkins, M. (2008). Poverty, loss, and resilience: The story of Asian immigrant youth. Journal of Counseling Psychology, 55, 34-48. https://doi.org/10.1037/0022-0167.55.1.34

Yeh, C. J., Ma, P-W., Madan, A., Hunter, C. D., Jung, S., Kim, A., Akitaya, K., \& Sasaki, K. (2005). The cultural negotiations of Korean immigrant youth. Journal of Counseling and Development, 83, 172-181. https://doi.org/10.1002/j.1556-6678.2005.tb00594.X

Yeh, C. J., Okubo, Y., Cha, N., Lee, S. J., \& Shin, S-Y. (2008b). Evaluation of an Intervention Program for Chinese Immigrant Adolescents' Cultural Adjustment. Journal of Immigrant \& Refugee Studies, 6(4), 567-590. doi:10.1080/15362940802480597

Yeh, C. J., Okubo, Y., Ma, P-W., Shea, M., Ou, D., \& Pituc, S. T. (2008a). Chinese immigrant high school students' cultural interactions, acculturation, family obligations, language use, and social support. Adolescence, 43, 775-790.

\section{Appendix}

\section{Program Overview}

\begin{tabular}{|c|c|c|}
\hline Session & Theme & Description \\
\hline 1 & $\begin{array}{l}\text { Introduction and } \\
\text { Data Collection }\end{array}$ & $\begin{array}{l}\text { Overview of goals, gather pre-entry data and student and parent/guardian } \\
\text { consent }\end{array}$ \\
\hline 2 & $\begin{array}{l}\text { Hopes and Fears about Life after } \\
\text { High School }\end{array}$ & $\begin{array}{l}\text { Exploring students' hopes and fears about life after high school. Hearing } \\
\text { stories from individuals who overcame odds to be the first in their family to } \\
\text { graduate from college. }\end{array}$ \\
\hline 3 & $\begin{array}{l}\text { Understanding my Family and } \\
\text { Cultural Background }\end{array}$ & $\begin{array}{l}\text { Understanding family obligations and cultural strengths needed to access } \\
\text { post-secondary plans. Developing a shared vision }\end{array}$ \\
\hline 4 & College 101 & Two and four-year college options in California \\
\hline 5 & $\begin{array}{l}\text { Debunking the Myth that "You } \\
\text { Can't Afford College" }\end{array}$ & $\begin{array}{l}\text { Comparing financial aid packages and considerations for first-generation } \\
\text { college and undocumented students. Scholarship information }\end{array}$ \\
\hline 6 & How to apply to college & $\begin{array}{l}\text { Learn about deadlines and the application process of two and four-year } \\
\text { schools in California }\end{array}$ \\
\hline $7-8$ & $\begin{array}{l}\text { Selecting and applying for } \\
\text { college }\end{array}$ & $\begin{array}{l}\text { Work sessions on filling out various college applications (e.g. community } \\
\text { colleges, CSUs, UCs, private/independent schools) }\end{array}$ \\
\hline 9 & $\begin{array}{l}\text { Identifying strengths and } \\
\text { resources to help me in this } \\
\text { transition }\end{array}$ & $\begin{array}{l}\text { Identifying assets and supportive people that can help with the application } \\
\text { process and in the transition to post-secondary plans }\end{array}$ \\
\hline 10 & $\begin{array}{l}\text { Next steps, closing, and } \\
\text { Data Collection }\end{array}$ & $\begin{array}{l}\text { Gather post-entry data, debrief sessions, terminate, and follow-up with parent/ } \\
\text { guardian }\end{array}$ \\
\hline
\end{tabular}

\section{Copyrights}

Copyright for this article is retained by the author(s), with first publication rights granted to the journal.

This is an open-access article distributed under the terms and conditions of the Creative Commons Attribution license (http://creativecommons.org/licenses/by/4.0/). 